\title{
Pengaruh MVA, DER, Serta EPS Terhadap Harga Saham Perusahaan Restoran, Hotel dan Pariwisata
}

\author{
Natalia \\ Universitas Prima Indonesia \\ Medan, Indonesia \\ nataliatnd98@gmail.com \\ Melvina \\ Universitas Prima Indonesia \\ Medan, Indonesia \\ melvina1998@yahoo.com
}

\author{
Arie Pratania Putri \\ Universitas Prima Indonesia \\ Medan, Indonesia \\ arieprataniaputri@gmail.com \\ Jenni \\ Universitas Prima Indonesia \\ Medan, Indonesia \\ jenniong90@gmail.com
}

\author{
Kelin Wijaya \\ Universitas Prima Indonesia \\ Medan, Indonesia \\ kelinwijaya@gmail.com
}

Corresponding Author : Arie Pratania Putri

Submitted: 6 Agustus 2020

Accepted: 25 Agustus 2020

Published: 25 Agustus 2020

\begin{abstract}
ABSTRAK
Saham adalah salah satu dana yang sangat penting bagi perusahaan. Naik turunnya harga saham mendapat pengaruh dari banyak faktor yang mempengaruhinya. Penelitian ini dilakukan untuk menguji pengaruh dari Market Value Added, Debt to Equity Ratio, serta Earning Per Share terhadap harga saham pada perusahaan sub sektor restoran, hotel, dan pariwisata yang terdaftar di Bursa Efek Indonesia tahun 2014-2017. Dengan menggunakan teknik purposive sampling, jumlah sampel penelitian yang memenuhi kriteria sebanyak 16 perusahaan sub sektor restoran, hotel dan pariwisata yang terdaftar di BEI periode 20142017. Sumber data yang digunakan adalah data sekunder berupa laporan keuangan tahunan. Penelitian ini menggunakan metode kuantitatif. Teknik analisis yang digunakan adalah regresi berganda, Uji hipotesis menggunakan uji-t serta uji-F dengan tingkat signifikansi 5\%. Pengujian asumsi klasik yang digunakan meliputi uji normalitas, heterokedastisitas, multikolinearitas, dan autokorelasi. Uji statistik menggunakan SPSS v25. Hasil uji koefisien determinasi menunjukkan bahwa $55.30 \%$ terdapat pengaruh variable dependen terhadap harga saham dan $44.70 \%$ dipengaruhi oleh variabel lain.Berdasarkan penelitian diperoleh hasil bahwa Market Value Added, Debt to Equity Ratio, serta Earning Per Share berpengaruh positif terhadap harga saham perusahaan restoran, hotel dan pariwisata yang terdaftar di BEI pada tahun 2014-2017 secara parsial maupun simultan.
\end{abstract}

Keywords : Market Value Added, Debt to Equity Ratio, Earning Per Share, Harga Saham 


\section{PENDAHULUAN}

Manajemen perusahaan yang baik dapat mewujudkan tujuan perusahaan serta memberi dampak terhadap pertumbuhan ekonomi negara. Pariwisata adalah sektor ekonomi yang penting bagi suatu negara, pariwisata berdampak kepada bukan hanya masyarakat di daerah tersebut tetapi jugaterhadap perusahaan akomodasi, restaurant, dan sebagainya. Sektor pariwisata Indonesia sangat berpengaruh dalam menambah devisa negara. Hal tersebut tidak lepas dari perkembangan daerah pariwisata yang ada di Indonesia. Pariwisata sangatlah penting untuk kemajuan dan pertumbuhan suatu daerah dan merupakan sumber pendapatan yang cukup efektif. Untuk menjangkau daerah pariwisata tersebut kita perlu merenovasi sarana dan prasarana daerah pariwisata sehingga dapat terus terjaga dengan baik. Secara tidak langsung sektor pariwisata ini dapat diartikan sebagai investasi yang sangat penting yang ada di Indonesia.

Berdasarkan berita di kompas.com pada tanggal $22 \quad$ Februari 2017 (https://ekonomi.kompas.com/read/2017/ 02/22/151709026/naik.22.54.persen.saha m.emiten.jasa.pariwisata.ini.diawasi.burs a) salah satu perusahaan yang berada dalam sektor pariwisata mengalami kenaikan harga saham. Harga saham PT Destinasi Tirta Nusantara Tbk (PDES) yang bergerak dalam bidang biro perjalanan wisata pada tanggal 2 Februari 2017 berada di level 8.650 per saham dan pada tanggal 22 Februari harga saham PDES berada pada level 10.600 atau naik 22,54 persen. Kenaikan tersebut menyebabkan PT Bursa Efek Indonesia (BEI) menetapkan PDES dalam kategori Unusual Market Activity (UMA). UMA ialah aktifitas perdagangan dan/atau pergerakan harga suatu Efek yang tidak biasa pada suatu kurun waktu tertentu di Bursa yang menurut penilaian Bursa dapat berpotensi menggangu terselenggaranya perdagangan efek yang teratur, wajar dan efisien.
Market Value Added (MVA) yang rendah berarti kinerja perusahaan yang kurang baik sehingga para investor kurang ingin membeli saham di perusahaan tersebut. Penelitian yang dilakukan oleh Sri Rahayu \& Dana (2016) dengan judul "Pengaruh EVA, MVA dan Likuiditas Terhadap Harga Saham pada Perusahaan Food and Beverage" menyatakan bahwa MVA berpengaruh positif signifikan terhadap harga saham

Debt to Equity Ratio (DER) berguna sebagai pengukur tingkatan Leverage (penggunaan hutang) terhadap total ekuitas suatu perusahaan. DER yang meningkat akan berpengaruh negative terhadap kinerja perusahaan, hutang suatu perusahaan yang tinggi akan menurunkan minat investor dalam berinvestasi di perusahaan yang dapat mempengaruhi harga saham di perusahaan tersebut. Judul penelitian "Pengaruh ROE dan DER terhadap Harga Saham Perusahaan Kertas di Bursa Efek Indonesia" yang dilakukan oleh Munira et al. (2018) menunjukkan bahwa DER memiliki pengaruh terhdapa harga saham.

Earning Per Share (EPS) digunakan untuk mengevaluasi aktivitas perusahaan yang mempengaruhi harga saham. Jika EPS naik berarti investor mendapatkan keuntungan yang besar, sehingga akan banyak investor yang berminat membeli saham di perusahaan tersebut. Ghozali (2013) dalam penelitian yang berjudul "Pengaruh Return On Asset (ROA), Earning Per Share (EPS), dan Debt To Equity Ratio (DER) terhadap harga saham (studi pada perusahaan properti yang listing di bursa efek Indonesia tahun 20072011" menyatakan bahwa EPS berpengaruh terhadap harga saham.

Penelitian ini terkait dengan penelitian yang telah dilakukan oleh Puspita et al. (2015). Dalam penelitiannya menyatakan bahwa MVA lebih mampu menciptakan ukuran penciptaan nilai bagi pemegang saham, karena nilai pasar ditandai dengan perolehan besarnya nilai perusahaan yang 
diharga pada pasar saham, yang merupakan pengali antara harga saham dengan jumlah saham yang beredar, sehingga kekayaan dan kesejahteraan pemilik perusahaan akan bertambah jika MVA nya bertambah. Dalam penelitian yang dilakukan oleh Febriyani (2017) dinyatakan bahwa penilaian investor terhadap hutang sebuah perusahaan tergantung dari bagaimana perusahaan mampu mengelola hutangnya dan penggunaan hutang itu sendiri, sehingga investor dapat menilai positif keberadaan hutang tersebut jika hutang tersebut dikelola dengan baik. Penelitian ini juga sejalan dengan penelitian yang dilakukan oleh Ifadhila (2016) dimana hasilnya menunjukkan bahwa variabel EPS memiliki pengaruh positif dan signifikan terhadap harga saham.

Tabel 1 : Data Fenomena Tahun 20142017 (dalam Ribuan Rupiah)

\begin{tabular}{|c|c|c|c|c|c}
\hline Kode & Tahun & Laba & Total Hutang & $\begin{array}{c}\text { Jumlah Saham } \\
\text { Beredar }\end{array}$ & Harga Saha \\
\hline ICON & 2014 & 5.385 .331 .532 & 123.749 .640 .977 & 1.000 .000 .000 & 448 \\
\hline & 2015 & 3.915 .155 .783 & 255.522 .508 .449 & 1.000 .000 .000 & 605 \\
\hline & 2016 & 4.360 .175 .368 & 309.737 .600 .921 & 2.750 .000 .000 & 500 \\
\hline & 2017 & 15.161 .894 .772 & 244.118 .030 .782 & 2.750 .000 .000 & 139 \\
\hline BAYU & 2014 & 38.586 .673 .501 & 256.550 .015 .014 & 960.000 .000 & 995 \\
\hline & 2015 & 26.137 .626 .931 & 268.776 .039 .936 & 960.000 .000 & 1.250 \\
\hline & 2016 & 27.209 .604 .516 & 280.845 .654 .069 & 960.000 .000 & 900 \\
\hline & 2017 & 32.945 .602 .411 & 354.038 .525 .426 & 960.000 .000 & 1.400 \\
\hline ARTA & 2014 & 11.266 .245 .955 & 60.355 .728 .778 & 850.000 .000 & 333 \\
\hline & 2015 & 1.484 .863 .368 & 59.932 .254 .237 & 850.000 .000 & 381 \\
\hline & 2016 & 4.606 .415 .870 & 61.025 .432 .615 & 850.000 .000 & 280 \\
\hline & 2017 & 11.595 .911 .507 & 66.431 .170 .779 & 850.000 .000 & 386 \\
\hline & & & & &
\end{tabular}

Sumber : $\underline{w w w . i d x . c o . i d}$

Pada tanggal 08 Juli 2005 PT. Island Concepts Indonesia Tbk terdaftar di bursa efek Indonesia. Berdasarkan tabel di atas, pada tahun 2014-2015 perusahaan tersebut mengalami penurunan laba sebesar 27,29\% dengan kenaikan harga saham sebesar 35\%. Penurunan juga terjadi pada akun total hutang perusahaan tahun 2016-2017, yakni sebesar 21,18\% dengan penurunan harga saham sebesar $72,2 \%$. Jumlah saham yang beredar pada tahun 2015-2016 meningkat sebesar $175 \%$ diikuti oleh penurunan harga saham sebesar $17,5 \%$.

PT. Bayu Buana Tbk yang terdaftar di
BEI tanggal 30 Oktober 1989 mengalami penurunan laba bersih sebesar 32,26\% dengan kenaikan harga saham sebesar 25,62\% di tahun 2014-2015. Di tahun yang sama terjadi kenaikan total hutang sebesar 4,76\% dengan kenaikkan harga saham sebesar 25,62\%. Dari tahun 20142017 jumlah saham beredar perusahaan tidak mengalami peningkatan maupun penurunan.

Tabel di atas menunjukkan bahwa, PT. Arthavest Tbk yang terdaftar di BEI pada tanggal 05 November 2002 mengalami kenaikan laba bersih sebesar 210,22\% di tahun 2015-2016 dengan penurunan harga saham sebesar 26,5\%. Di tahun 20162017 perusahaan mengalami kenaikan total hutang sebesar $8,85 \%$ dengan kenaikan harga saham sebesar $37,85 \%$. PT. Arthavest Tbk selama tahun 20142017 juga tidak mengalami peningkatan maupun penurunan terkait jumlah saham yang beredar.

Berdasarkan fenomena dan penelitian diatas, maka dilakukanlah penelitian yang berjudul "Pengaruh Market Value Added, Debt to Equity Ratio, serta Earning Per Shareterhadap Harga Saham Perusahaan Restoran, Hotel dan Pariwisata”.

\section{TINJAUAN PUSTAKA \\ 2.1 Harga Saham}

Menurut Jogiyanto (2008:167) harga saham adalah "Harga yang terjadi pada saham di pasar bursa di keadaan tertentu yang ditentukan oleh pelaku saham serta penawaran dan permintaan saham di pasar modal yang bersangkutan".

\subsection{Market Value Added (MVA)}

Winarto (2010:4) pengertian MVA adalah perbedaan terhadap keuntungan sekarang dengan modal yang ditanamkan perusahaan (seperti pinjaman, modal, laba ditahan, dan lain-lain) yang adalah selisih nilai pasar dan nilai buku dari seluruh tuntutan modal.

Sartono, 2010:103 menyatakan bahwa indikator MVA ialah : 


$$
M V A=(J S B * H S)-T M
$$

\section{Keterangan :}

MVA = Market Value Added

JSB = Jumlah Saham Beredar

HS = Harga Saham

Menurut (Husnan dan Pudjiastuti, 2015) MVA yang besar menandakan bahwa manajemen berhasil dalam mengelola perusahaannya. Jika nilai MVA perusahaan besar maka akan meningkatkan harga saham perusahaan tersebut. Pernyataan tersebut diperkuat oleh penelitian yang dilakukan Utami \& Darmawan (2018) yang menyatakan bahwa Market Value Added (MVA) berpengaruh positif terhadap harga saham.

\subsection{Debt to Equity Ratio (DER)}

Menurut Kasmir (2012 : 158) DER digunakan untuk menilai rasio diantara ekuitas dan hutang. DER menunjukkan besar penggunaan dana dari hutang suatu perusahaan dan juga kemampuan dari perusahaan tersebut memenuhi kewajibannya.

Menurut Mamduh M Hanafi dan Abdul Halim (2012:79) indikator DER ialah :

$$
\text { DER }=\frac{\text { Total Liabilities }}{\text { Total Equity }}
$$

Berdasarkan penelitian yang dilakukan oleh Nurmala Alfiah dan Lucia Ari Diyani (2017) DER berpengaruh signifikan terhadap harga saham perusahaan. Karena pinjaman perusahaan dapat menjadi acuan investor dalam menanamkan sahamnya. DER yang tinggi menandakan bahwa perusahaan memiliki resiko yang tinggi hingga investor cenderung menghindari perusahaan tersebut dan mengakibatkan permintaan saham menurun dan dapat memicu turunnya harga saham.

\subsection{Earning Per Share (EPS)}

Menurut Darmaji dan Fakhruddin
(2006:195) EPS digunakan untuk menggambarkan bagian laba setiap saham. EPS menunjukkan profitabilitas perusahaan yang ada pada setiap lembar saham.

Menurut Eduardus Tandelilin, 2010:374, EPS dapat dihitung melalui rumus di bawah ini :

$$
\text { EPS }=\frac{\text { Laba bersih }}{\text { Jumlah Saham Beredar }}
$$

Darmadji (2001:139) menyatakan bahwa semakin tinggi nilai EPS perusahaan maka akan menggembirakan pemegang saham karena laba yang besar menandakan bahwa perusahaan dapat memberikan tingkat keuntungan kepada para pemegang saham, sebaliknya jika EPS yang rendah dapat memberikan tingkat keuntungan yang rendah kepada para pemegang saham. Tinggi rendahnya tingkat EPS akan menyebabkan tingkat harga saham perusahaan tersebut. Hal itu diperkuat dengan penelitian yang dilakukan oleh Wicaksono (2015) , dimana ia menyatakan bahwa EPS berpengaruh secara signifikan terhadap harga saham perusahan.

\section{METODE PENELITIAN}

\subsection{Jenis Penelitian}

Penelitian deskriptif ialah jenis penelitian yang digunakan dalam penelitian ini. Nazir (1998:63) menyatakan bahwa jenis ini meneliti tentang status sekelompok manusia, objek, suatu kondisi, suatu pemikiran maupun suatu peristiwa.

\subsection{Sifat Penelitian}

Penelitian ini bersifat penelitian eksplanatori (Explanatory Research). Dimana menurut Umar (1996:36) penelitian ini bersifat menganalisis hubungan-hubungan antara satu variable dengan variable lainnya. 


\subsection{Populasi dan Sampel}

Semua perusahaan sub sector restoran, hotel dan pariwisata yang terdaftar (listed) di Bursa Efek Indonesia (BEI) sejak tahun 2014-2017 merupakan populasi yang digunakan dalam penelitian ini. Populasi yang digunakan berjumlah 35 perusahaan.

Adapun kriteria-kriteria dalam pemilihan sampel ialah sebagai berikut;

1. Sub sektor perusahaan restoran, hotel dan pariwisata yang terdaftar di Bursa Efek Indonesia (BEI) pada periode 20142017

2. Sub sektor perusahaan restoran, hotel dan pariwisata yang memiliki laba positif secara berturut-turut pada periode 20142017.

Tabel 2 : Pemilihan Sampel

\begin{tabular}{|r|l|c|}
\hline No & \multicolumn{1}{|c|}{ Keterangan } & Jumlah \\
\hline 1 & $\begin{array}{l}\text { Sub sektor } \\
\text { perusahaan } \\
\text { restoran, hotel dan } \\
\text { pariwisata yang } \\
\text { terdaftar di Bursa } \\
\text { Efek Indonesia } \\
\text { (BEI) pada periode } \\
\text { 2014-2017 }\end{array}$ & \\
\hline 2 & $\begin{array}{l}\text { Sub sektor } \\
\text { perusahaan } \\
\text { restoran, hotel dan } \\
\text { pariwisata yang } \\
\text { mengalami } \\
\text { kerugian pada } \\
\text { periode 2014- } \\
\text { 2017. }\end{array}$ \\
\hline & $\begin{array}{l}\text { Jumlah sampel } \\
\text { penelitian }\end{array}$ & 16 \\
\hline
\end{tabular}

\subsection{Jenis dan Sumber Data Penelitian}

Penelitian ini menggunakan metode kuantitatif yaitu metode yang memberikan gambaran mengenai suatu objek atau peristiwa. Data penelitian merupakan data sekunder, bersumber dari laporan keuangan sub sector restoran, hotel dan pariwisata yang dimuat dalam situs resmi
Bursa Efek Indonesia pada tahun 20142017, yaitu www.idx.co.id.

\subsection{Metode Analisis Data Penelitian 3.5.1 Model Penelitian}

Uji asumsi klasik dan uji hipotesis dilakukan terlebih dahalu sebelum dilakukannya metode analisis statistik. Uji tersebut bertujuan untuk keperluan analisis data. SPSS atau Statistical Product and Service Solution ialah aplikasi yang biasanya digunakan untuk mengolah data yang akan dianalisis.

Untuk mengetahui pengaruh variabel independen terhadap variable dependen digunakan rumus analisis regresi berganda sebagai berikut :

$$
Y=a+b_{1} X_{1}+b_{2} X_{2}+b_{3} X_{3}+e
$$

Keterangan :

$\mathrm{Y}=$ Harga saham

$\mathrm{a}=$ Konstanta

b1,b2,b3, b4= Koefisien Regresi

$\mathrm{X} 1=$ Variabel Market Value Added

$\mathrm{X} 2=$ Variabel Debt to Equity Ratio

X3 = Variabel Earning Per Share

$\mathrm{e} \quad=$ Estimasi Kesalahan

\subsubsection{Pengujian Hipotesis secara Simultan}

a. $\mathrm{H}_{0}$ diterima atau $\mathrm{H}_{\mathrm{a}}$ ditolak jika $\mathrm{F}_{\text {hitung }}$ $\leq \mathrm{F}_{\text {tabel }}$ dan nilai sig $>0,05$.

b. $\mathrm{H}_{\mathrm{a}}$ diterima atau $\mathrm{H}_{0}$ ditolak jika $F_{\text {hitung }}>F_{\text {tabel }}$ dan nilai sig $<0,05$.

\subsubsection{Pengujian Hipotesis secara Parsial}

a. $\mathrm{H}_{0}$ diterima atau $\mathrm{H}_{\mathrm{a}}$ ditolak jika $\mathrm{t}_{\text {hitung }}$ $\leq \mathrm{t}_{\text {tabel }}$ dan nilai sig $>0,05$.

b. $\mathrm{H}_{\mathrm{a}}$ diterima atau $\mathrm{H}_{0}$ ditolak jika $\mathrm{t}_{\text {hitung }}<\mathrm{t}_{\text {tabel }}<\mathrm{t}_{\text {hitungdan nilai sig }}<0,05$.

\section{HASIL DAN PEMBAHASAN}

\subsection{Statistik Deskriptif}

Tabel 3 : Statistik Deskriptif Descriptive Statistic

\begin{tabular}{|c|c|c|c|c|c|}
\hline & $\mathrm{N}$ & $\begin{array}{c}\text { Minim } \\
\text { um }\end{array}$ & $\begin{array}{c}\text { Maxim } \\
\text { um }\end{array}$ & Mean & $\begin{array}{c}\text { Std. } \\
\text { Deviati } \\
\text { on }\end{array}$ \\
\hline
\end{tabular}




\begin{tabular}{|c|r|r|r|r|r|}
\hline HS & 64 & 50.00 & 2560.0 & 750.62 & 640.86 \\
6 & 50 & 686 \\
\hline M & 64 & $\begin{array}{r}29189 \\
00000\end{array}$ & $\begin{array}{r}59333 \\
10000 \\
\text { VA }\end{array}$ & 563135 & 148039 \\
000 & 000 & .09 & 930124 \\
2.891 \\
\hline $\begin{array}{c}\text { DE } \\
\text { R }\end{array}$ & 64 & .14 & 3.23 & .7066 & .59600 \\
\hline $\begin{array}{c}\text { EP } \\
\text { S }\end{array}$ & 64 & .00 & 261.33 & 32.947 & 54.943 \\
\hline $\begin{array}{c}\text { Val } \\
\text { id } \\
\text { N } \\
\text { list } \\
\text { wis } \\
\text { e) }\end{array}$ & 64 & & & 5 & 42 \\
\hline
\end{tabular}

Sumber : Data diolah dengan SPSS 25,2020

a) Nilai standar deviasi harga saham sebesar 640.86686. Nilai mean harga saham sebesar 750.6250. Harga Saham tertinggi sebesar 2560,00 dan paling terendah yaitu sebesar 50,00

b) MVA sebesar 5933310000000 dimiliki oleh data perusahaan PT Jakarta Setiabudi Internasional Tbk (JSPT) pada tahun 2016 dan MVA terendah sebesar 2918900000000 dimiliki oleh data perusahaan PT MNC Land Tbk (KPIG) pada tahun 2017. Nilai mean dan standar deviasi MVA sebesar 563135051031.09 dan 1480399301242.891.

c) DER tertinggi sebesar 3.23 dimiliki oleh data perusahaan PT Panorama Sentra Wisata Tbk (PANR) pada tahun 2015 dan DER terendah sebesar 0.14 dimiliki oleh data perusahaan PT Pembangunan Graha Lestari Tbk (PGLI) pada tahun 2015. Nilai mean dan standar deviasi DER sebesar 0.7066 dan 0.59600 .

d) EPS tertinggi sebesar 261.33 dimiliki oleh data perusahaan PT MNC Land Tbk (KPIG) pada tahun 2016 dan EPS terendah sebesar 0.00 dimiliki oleh data perusahaan PT Panorama Sentra Wisata Tbk (PANR) pada tahun 2016. Dengan nilai mean dan standar deviasi sebesar 32.9475 dan 54.94342.

\subsection{Uji Asumsi Klasik 4.2.1 Uji Normalitas}

Uji normalitas bertujuan untuk menguji apakah sampel yang digunakan ter distribusi secara normal atau tidak. Uji normalitas pada penelitian ini menggunakan grafik histogram, Probability Plot, dan uji Kolmogorov Smirnov.

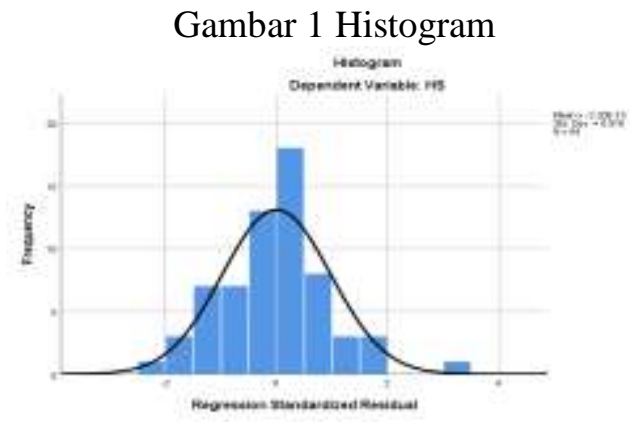

Sumber : Data diolah dengan SPSS 25,2020

Gambar 2 Normal Probability Plot

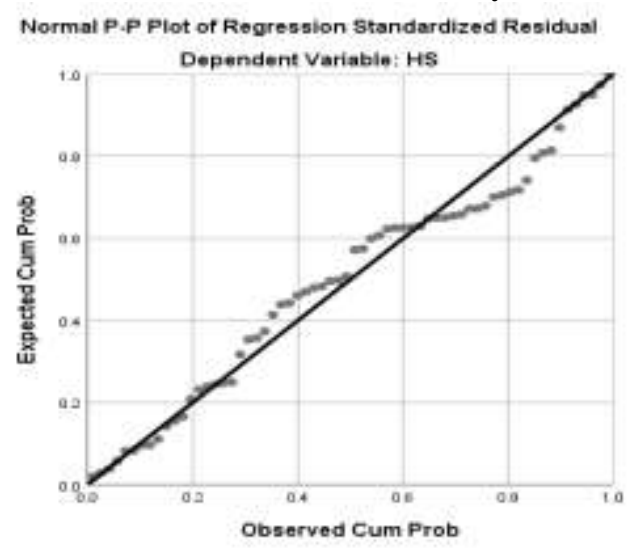

Sumber : Data diolah dengan SPSS 25, 2020

Berdasarkan gambar 3.1 dan 3.2 diatas dapat dilihat grafik histogram menunjukkan pola data terdistribusi secara normal, karena bentuk kurva pada histrogram memiliki bentuk seperti lonceng dan pola distribusi yang melenceng ke kanan. Gambar P-plot terlihat titik-titik yang mengikuti dan menyebar di sekitar garis diagonal dan 
mengikuti arah garis diagonal sehingga dapat disimpulkan bahwa model regresi memenuhi asumsi normalitas.

Tabel 4 : Hasil One-Sample KolmogrovSmimov Test

\begin{tabular}{|c|c|c|}
\hline \multicolumn{3}{|c|}{$\begin{array}{c}\text { One-Sample Kolmogorov-Smirnov } \\
\text { Test }\end{array}$} \\
\hline & & $\begin{array}{l}\text { Unstandardi } \\
\text { zed Residual }\end{array}$ \\
\hline \multicolumn{2}{|l|}{$\mathrm{N}$} & 64 \\
\hline \multirow{2}{*}{$\begin{array}{l}\text { Normal } \\
\text { Parameters } \\
\mathrm{a}, \mathrm{b}\end{array}$} & Mean & .0000000 \\
\hline & $\begin{array}{l}\text { Std. } \\
\text { Deviation }\end{array}$ & .69146690 \\
\hline \multirow{3}{*}{$\begin{array}{l}\text { Most } \\
\text { Extreme } \\
\text { Difference } \\
\text { s }\end{array}$} & Absolute & .106 \\
\hline & Positive & .106 \\
\hline & Negative & -.078 \\
\hline \multicolumn{2}{|c|}{ Test Statistic } & .106 \\
\hline Asymp. Sig & (2-tailed) & $.074^{\mathrm{c}}$ \\
\hline \multicolumn{3}{|c|}{ a. Test distribution is Normal. } \\
\hline \multicolumn{3}{|c|}{ b. Calculated from data. } \\
\hline \multicolumn{3}{|c|}{ c. Lilliefors Significance Correction. } \\
\hline
\end{tabular}

Sumber : Data diolah dengan SPSS 25, 2020

Melalui uji One-sampel KolmogrovSmirnov Nilai Asymp. Sig.(2-tailed) menunjukkan nilai sebesar $0.074>0,05$ sehingga dapat disimpulkan bahwa residual terdistribusi normal yang berarti asumsi dasar kenormalan telah dipenuhi.

\subsubsection{Uji Multikolinieritas}

Tabel 5 : Uji Multikolonieritas

\begin{tabular}{|c|c|c|c|}
\hline \multicolumn{4}{|c|}{ Coefficients $^{a}$} \\
\hline \multirow{2}{*}{\multicolumn{2}{|c|}{ Model }} & \multicolumn{2}{|c|}{ Collinearity Statistics } \\
\hline & & Tolerance & VIF \\
\hline \multirow[t]{3}{*}{1} & MVA & .893 & 1.120 \\
\hline & DER & .955 & 1.047 \\
\hline & EPS & .933 & 1.072 \\
\hline
\end{tabular}

Sumber : Data diolah dengan SPSS 25, 2020

Berdasarkan tabel 3.3, nilai VIF untuk variabel independen MVA, DER dan EPS memiliki nilai yang lebih kecil dari 10 dan nilai tolerance tidak kurang dari 0.1 , sehingga dapat disimpulkan bahwa Market Value Added (MVA), Debt to Equity Ratio (DER) dan Earning per Share (EPS) tidak mengalami masalah multikolinieritas.

\subsubsection{Uji Heteroskedastisitas}

Gambar 3 : Grafik Scatter Plot uji Heteroskedastisi

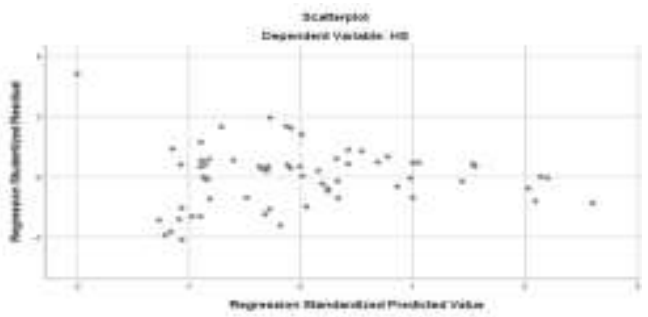

Sumber : Data diolah dengan SPSS 25, 2020

Hasil uji hetereroskedastisitas dengan menggunakan uji Scatter Plotdiatas menunjukkan bahwa titik-titik data tersebar diatas dan dibawah atau disekitar angka 0 . Titik-titik tidak mengumpul hanya diatas atau dibawah dan penyebaran titik-titik data tidak membentuk pola bergelombang melebar kemudian meyempit kembali. Sehingga dapat disimpulkan bahwa data tidak mengalami heteroskedastisitas. Selain menggunakan pengujian scatter plot, peneliti juga menggunakan uji Spearman'rho untuk memprediksi heteroskedastisitas. $\quad$ Tabel $\quad 3.4$ menunjukkan bahwa Nilai sig pada masing-masing variable menunjukkan nilai $>0.05$ sehingga disimpulkan bahwa model regresi tidak mengalami masalah heteroskedastisitas.

Tabel 6 : Hasil Uji Heteroskedastisitas

\begin{tabular}{|c|c|c|c|}
\hline & & & $\begin{array}{c}\text { Unstandar } \\
\text { dized } \\
\text { Residual }\end{array}$ \\
\hline \multirow{5}{*}{$\begin{array}{c}\text { Spea } \\
\text { rma } \\
\text { n's } \\
\text { rho }\end{array}$} & \multirow{3}{*}{ MVA } & $\begin{array}{l}\text { Correlation } \\
\text { Coefficient }\end{array}$ & .190 \\
\hline & & Sig. (2-tailed) & .133 \\
\hline & & $\mathrm{N}$ & 64 \\
\hline & \multirow[t]{2}{*}{ DER } & $\begin{array}{l}\text { Correlation } \\
\text { Coefficient }\end{array}$ & -.021 \\
\hline & & Sig. (2-tailed) & .870 \\
\hline
\end{tabular}




\begin{tabular}{|l|l|l|r|}
\hline & & $\mathrm{N}$ & 64 \\
\cline { 3 - 4 } & \multirow{4}{*}{ EPS } & $\begin{array}{l}\text { Correlation } \\
\text { Coefficient }\end{array}$ & -.043 \\
\cline { 3 - 4 } & Sig. (2-tailed) & .7 .34 \\
\cline { 2 - 3 } & $\mathrm{N}$ & 64 \\
\cline { 2 - 4 } $\begin{array}{l}\text { Unsta } \\
\text { ndardi } \\
\text { zed } \\
\text { Resid } \\
\text { Ral }\end{array}$ & $\begin{array}{l}\text { Correlation } \\
\text { ual }\end{array}$ & Soefficient & 1.000 \\
\cline { 2 - 4 } & $\mathrm{N}$ (2-tailed) & 64 \\
\hline
\end{tabular}

Sumber : Data diolah dengan SPSS 25, 2020

\subsubsection{Uji Autokolerasi}

Tabel 7 : Hasil Uji Autokolerasi

\begin{tabular}{|c|c|c|c|c|c|}
\hline \multicolumn{6}{|c|}{ Model Summary ${ }^{b}$} \\
\hline $\begin{array}{l}\text { M } \\
\text { od } \\
\text { el }\end{array}$ & $\mathrm{R}$ & $\begin{array}{c}\mathrm{R} \\
\text { Squar } \\
\mathrm{e}\end{array}$ & $\begin{array}{l}\text { Adjust } \\
\text { ed R } \\
\text { Square }\end{array}$ & $\begin{array}{c}\text { Std. } \\
\text { Error of } \\
\text { the } \\
\text { Estimate }\end{array}$ & $\begin{array}{c}\text { Durbi } \\
\text { n- } \\
\text { Wats } \\
\text { on }\end{array}$ \\
\hline 1 & .743 & .553 & .530 & .70854 & 2.221 \\
\hline
\end{tabular}

a. Predictors: (Constant), EPS, DER, MVA

b. Dependent Variable: HS

Sumber : Data diolah dengan SPSS 25, 2020

Nilai dL dan dU dapat dilihat pada Tabel DW dengan tingkat signifikansi (error) 5\% $(\mathrm{a}=0,05)$, sehingga diperoleh nilai $\mathrm{du}=1.695$ dan $\mathrm{dl}=.1 .499$. Berdasarkan tabel diatas nilai 1.695 < $2.221<2.305$ (4 - 1.695) sehingga dapat diambil kesimpulan yaitu tidak ada masalah autokorelasi pada model.

\subsection{Analisis Regresi Berganda}

Tabel 8 : Hasil Regresi

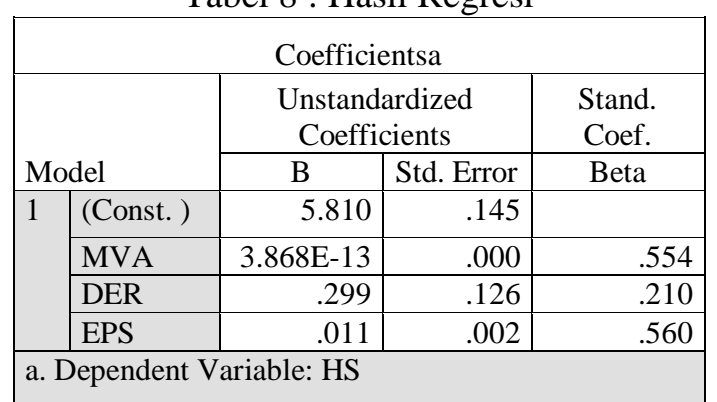

Sumber : Data diolah dengan SPSS 25, 2020
Berdasarkan hasil regresi diatas, model persamaan pada penelitian ialah :

$$
\text { HS } \quad=5.810+3868 \mathrm{E}-13
$$

MVA + 0.299 DER + 0.011 EPS

Persamaan diatas dapat dijelaskan bahwa:

a. Konstanta a sebesar 5.810, artinya apabila MVA, DER dan EPS sebesar 0 (tidak mengalami perubahan) maka harga saham sebesar 5.810 .

b. Nilai koefisien variabel MVA sebesar 3868E-13 menunjukan tanda positif. Hal ini menunjukkan bahwa MVA memiliki hubungan positif terhadap harga saham. Artinya apabila MVA mengalami kenaikan sebesar 1 satuan sementara DER dan EPS bersifat tetap maka variabel harga saham akan mengalami peningkatan sebesar 3868E-13.

c. Nilai koefisien variabel DER sebesar 0.299 menunjukan tanda positif. Hal ini menunjukkan bahwa DER memiliki hubungan positif terhadap harga saham. Artinya apabila DER mengalami kenaikan sebesar 1 satuan sementara MVA dan EPS bersifat tetap maka harga saham akan mengalami peningkatan sebesar 0.299.

d. Nilai koefisien variabel EPS sebesar 0.011 menunjukan tanda positif. Hal ini menunjukkan bahwa EPS memiliki hubungan positif terhadap harga saham. Artinya apabila EPS mengalami kenaikan sebesar 1 satuan sementara MVA dan DER bersifat tetap maka harga saham akan mengalami peningkatan sebesar 0.011 .

\subsection{Uji Hipotesis}

4.4.1 Koefisien Determinasi (R2)

Tabel 9: Koefisien Determinasi (R2)

\begin{tabular}{|l|c|c|c|c|}
\hline \multicolumn{5}{|c|}{ Model Summary } \\
\hline $\begin{array}{c}\text { Mo } \\
\text { del }\end{array}$ & $\mathrm{R}$ & $\begin{array}{c}\mathrm{R} \\
\text { Squar } \\
\mathrm{e}\end{array}$ & $\begin{array}{c}\text { Adjus } \\
\text { ted R } \\
\text { Squar } \\
\mathrm{e}\end{array}$ & $\begin{array}{c}\text { Std. } \\
\text { Error of } \\
\text { the } \\
\text { Estimate }\end{array}$ \\
\hline 1 & $.743^{\mathrm{a}}$ & .553 & .530 & .70854 \\
\hline
\end{tabular}




\begin{tabular}{|l|}
\hline a. Predictors: (Constant), EPS, DER, \\
MVA \\
\hline b. Dependent Variable: HS \\
\hline
\end{tabular}

Sumber : Data diolah dengan SPSS 25, 2020

Berdasarkan tabel diatas, diketahui RSquared (R2) sebesar 0.553. Hal ini menunjukkan bahwa proporsi pengaruh variabel MVA, DER, EPS terhadap harga saham sebesar $55.30 \%$ sedangkan sisanya $44.70 \%(100 \%$ - 55.30\%) dipengaruhi oleh variabel lain diluar model yang tidak diteliti.

\subsubsection{Uji F Simultan}

Tabel 10 : Hasil Uji Statistik F

\begin{tabular}{|l|l|r|c|}
\hline \multicolumn{3}{|c|}{ ANOVA } \\
\hline \multicolumn{2}{|c|}{ Model } & \multicolumn{1}{c|}{ F } & Sig. \\
\hline \multirow{2}{*}{1} & Regressi & 24.70 & $.000^{\mathrm{b}}$ \\
& on & 3 & \\
\cline { 2 - 4 } & Residual & & \\
\cline { 2 - 4 } & Total & & \\
\hline \multicolumn{2}{|c|}{ Dependent Variable: HS } \\
\hline \\
b. Predictors: (Constant), EPS, \\
DER, MVA \\
\hline
\end{tabular}

Sumber : Data diolah dengan SPSS 25, 2020

Nilai t tabel pada tingkat signifikansi 0.05 dan derajat bebas (df) adalah $\mathrm{df}=\mathrm{n}$ $\mathrm{k}-1=64-3-1=60$, sehingga diperoleh nilai $\mathrm{F}$ tabel sebesar 2.76. Hasil uji $\mathrm{F}$ adalah sebagai berikut. Berdasarkan tabel diatas, diperoleh nilai sig. F-statistic lebih kecil dari alpha (0.05) dan Fhitung $\geq$ Ftabel sebesar 24.703 > 2.76 yang artinya MVA, DER dan EPS berpengaruh signifikan terhadap harga saham. Selain itu dapat dilihat pada nilai signifikansi menunjukkan bahwa nilai signifikant level pada tabel sebesar 0,000 . Hal ini berarti Nilai signifikannya $<0,05$. Dengan kata lain $\mathrm{Ho}$ ditolak sedangkan $\mathrm{Ha}$ diterima , sehingga kesimpulan dalam penelitian ini ialah MVA, DER, dan EPS berpengaruh secara simultan/bersama terhadap harga saham pada perusahaan pariwisata.

\subsubsection{Uji t}

Nilai t tabel pada tingkat signifikansi 0.05 dan derajat bebas (df) adalah $\mathrm{df}=\mathrm{n}$ $\mathrm{k}-1=64-3-1=60$, sehingga diperoleh nilai $\mathrm{t}$ tabel sebesar 2.000. Hasil uji t parsial dapat dilihat pada tabel dibawah ini :

Tabel 11 : Uji Statistik t

\begin{tabular}{|l|c|c|c|}
\hline \multicolumn{3}{|c|}{ Coefficients $^{\mathrm{a}}$} \\
\hline \multicolumn{2}{|c|}{ Model } & $\mathrm{t}$ & Sig. \\
\hline \multicolumn{2}{|c|}{$\begin{array}{l}\text { (Constant } \\
\text { ) }\end{array}$} & 40.143 & .000 \\
\hline MVA & 6.061 & .000 \\
\hline DER & 2.376 & .021 \\
\hline \multicolumn{2}{|l|}{ EPS } & 6.259 & .000 \\
\hline \multicolumn{2}{|c|}{ a.Dependent Variable: HS } \\
\hline
\end{tabular}

Sumber : Data diolah dengan SPSS 25, 2020

Berdasarkan hasil pengujian pada tabel diatas, diketahui bahwa Nilai prob. variabel MVA $<$ nilai probabilitas kritis $(\alpha$ $=5 \%)$ sebesar $0.000<0,05$ dan nilai $\mathrm{t}_{\text {hitung }}>\mathrm{t}$ tabel yaitu $6.061>2.000$. Nilai prob. Variabel DER $<$ nilai probabilitas kritis $(\alpha=5 \%)$ sebesar $0.021<0,05$ dan nilai $t_{\text {hitung }}>t_{\text {tabel }}$ yaitu $2.376>2.000$.Nilai prob. variabel EPS $<$ nilai probabilitas kritis $(\alpha=5 \%)$ sebesar $0.000<0,05$ dan nilai $t_{\text {hitung }}>\mathrm{t}_{\text {tabel }}$ yaitu $6.259>2.000$.

Agus Sartono (2008:103) menyatakan bahwa kemakmuran pemegang saham dimaksimumkan dengan memaksimumkan kenaikan nilai pasar dari modal perusahaan di atas nilai modal yang disetor pemegang saham. Stella (2009:100) menyatakan bahwa DER yang tinggi menunjukkan tingginya ketergantungan permodalan perusahaan terhadap pihak luar, sehingga beban perusahaan juga semakin berat. Menurut Widoatmodjo dalam Priatina (2012:54), EPS sangat berpengaruh terhadap harga saham. Semakin tinggi EPS maka akan semakin mahal harga saham perusahaan terebut, karena EPS merupakan salah satu 
bentuk rasio keuangan untuk menilai kinerja perusahaan.

Hasil penelitian diatas menunjukkan bahwa Hipotes 1, Hipotes 2 dan Hipotes 3 diterima. Dimana MVA berpengaruh secara positif dan signifikan terhadap harga saham. DER berpengaruh secara positif dan signifikan terhadap harga saham. Perusahaan yang menanggung beban utang yang rendah dari modal yang dimiliki akan menaikkan harga saham perusahaan karena kepercayaan investor terhadap manajemen keuangan perusahaan. EPS berpengaruh secara positif dan signifikan terhadap harga saham. Tingkat laba bersih yang tinggi mempengaruhi harga saham perusahaan karena investor menganggap kinerja perusahaan yang baik.

\section{KESIMPULAN DAN SARAN \\ 5.1 Kesimpulan}

Berdasarkan hasil dan pembahasan diatas maka dapat diambil kesimpulan bahwa Market Value Added (MVA), Debt to Equity Ratio (DER), dan Earning Per Share (EPS) berpengaruh secara simultan/bersama terhadap harga saham pada perusahaan sub sektor restoran, hotel dan pariwisata yang terdaftar dalam BEI periode 2014-2017. Dibuktikan dengan hasil uji $F$ menghPUSasilkan nilai $F_{\text {hitung }} \geq F_{\text {tabel }}$ sebesar $24.703>2.76$ serta nilai signifikansi sebesar $0.00<0.05$.

Market Value Added (MVA), berpengaruh secara parsial terhadap harga saham pada perusahaan sub sektor restoran, hotel dan pariwisata yang terdaftar dalam BEI periode 2014-2017. Dibuktikan dengan hasil uji $t$ menghasilkan nilai $t_{\text {hitung }}>t_{\text {tabel }}$ yaitu 6.061 $>2.000$.Debt to Equity Ratio (DER) berpengaruh secara parsial terhadap harga saham pada perusahaan sub sektor restoran, hotel dan pariwisata yang terdaftar dalam BEI periode 2014-2017. Dibuktikan dengan hasil uji $t$ menghasilkan nilai $t_{\text {hitung }}>t_{\text {tabel }}$ yaitu 6.376 >2.000. Earning Per Share (EPS) berpengaruh secara parsial terhadap harga saham pada perusahaan sub sektor restoran, hotel dan pariwisata yang terdaftar dalam BEI periode 2014-2017. Dibuktikan dengan hasil uji $t$ menghasilkan nilai $t_{\text {hitung }}>t_{\text {tabel }}$ yaitu 6.259 $>2.000$.

\subsection{Saran}

Setelah dilakukan penelitian ini, ada beberapa hal yang dapat disampaikan peneliti dan sekiranya dapat bermanfaat untuk kedepannya:

1. Calon investor ada baiknya melakukan analisis terlebih dahulu sebelum membuat keputusan investasi. Dalam hal ini investor maupun calon investor harus cermat dalam menilai harga saham perusahaan sehingga bisa mengetahui bagaimana prospek bisnis perusahaan kedepannya.

2. Bagi peneliti selanjutnya diharapkan dapat menambah variabel-variabel lain yang diduga dapat mempengaruhi harga saham pada perusahaan sub sektor restoran, hotel dan pariwisata.

\section{REFERENSI}

Alfiah, N., \& Diyani, L. A. (2018). Pengaruh Roe Dan Der Terhadap Harga Saham Pada Sektor Perdagangan Eceran. Jurnal Bisnis Terapan, $1(02), \quad 47$. https://doi.org/10.24123/jbt.v1i02.7 94

Darmadji, T., \& Fakhrudin. (2006). Pasar Modal di Indonesia Pendekatan Tanya Jawab. Salemba Empat.

Febriyani, R. M. (2017). Pengaruh Return on Asessets, Debt to Equity Ratio dan Deviden Payout Ration terhadap Harga Saham. (Studi Pada Perusahaan Indeks LQ 45 Tahun 2011-2015) [UPY]. http://repository.upy.ac.id/id/eprint/ 1338.

Ghozali, F. (2013). Pengaruh Return On Asset (ROA), Earning Per Share (EPS), dan Debt To Equity Ratio 
(DER) terhadap harga saham (studi pada perusahaan properti yang listing di bursa efek Indonesia tahun 2007-2011). Universitas Brawijaya.

Hanafi, M., \& Hakim, A. (2012). Analisis Laporan Keuangan. UPP STIM YKPN.

Husein, U. (1996). Metode penelitiaan untuk skripsi dan tesis bisnis. PT. Raja Grafindo Persada.

Husnan, S., \& Pudjiastuti, E. (2015). Dasar-Dasar Manajemen Keuangan, Edisi Ketujuh. UPP STIM YKPN.

Ifadhila, I. (2016). Pengaruh Earnings Per Share (EPS) dan Price Earnings Ratio (PER) terhadap Harga Saham dengan Dividend Per Share (DPS) sebagai Variabel Moderasi pada Perusahaan yang Terdaftar di Jakarta Islamic Index (JII) [Universitas Islam Negeri Alauddin Makassar]. http://repositori.uinalauddin.ac.id/5033/

Jogiyanto. (2008). Teori Portofolio dan Analisis Investasi. Edisi Kelima. BPFE.

Kasmir. (2012). Analisis Laporan Keuangan. PT. Raja Grafindo Persada

Kusuma, P. A., \& Priantinah, D. (2012). Pengaruh Return on Investment (Roi), Earning Per Share (Eps), Dan Dividen Per Share (Dps) Terhadap Harga Saham Perusahaan Pertambangan Yang Terdaftar Di Bursa Efek Indonesia (Bei) Periode 2008-2010. Nominal, Barometer Riset Akuntansi Dan Manajemen, 1(2).

https://doi.org/10.21831/nominal.v1 i2.998

Munira, M., Merawati, E. E., \& Astuti, S. B. (2018). Pengaruh ROE dan DER Terhadap Harga Saham Perusahaan Kertas di Bursa Efek Indonesia. JABE (Journal of Applied Business and Economic), 4(3), 191-205.
Nazir, M. (1998). Metode Penelitian. Ghalia Indonesia.

Puspita, V., Banaludin, I., \& Umrie, R. H. (2015). Pengaruh Economic Value Added (EVA) dan Market Value Added (MVA) terhadap Harga Saham pada perusahaan LQ-45 Di Bursa Efek Indonesia. Jurnal Ilmiah Manajemen, Universitas Sriwijaya. https://doi.org/10.29259/jmbt.v12i2. 3091

Sartono, A. (2010). Manajemen Keuangan: Teori dan Aplikasi. BPFE Yogyakarta.

Sri Rahayu, N., \& Dana, I. (2016). Pengaruh Eva, Mva Dan Likuiditas Terhadap Harga Saham Pada Perusahaan Food and Beverages. EJurnal Manajemen Universitas Udayana, 5(1), 253521.

Stella. (2009). Pengaruh Price to Earnings Ratio, Debt to Equity Ratio, Return On Asset, dan Price to Book Value terhadap Harga Pasar Saham. Jurnal Bisnis Dan Akuntansi, 11(2), 97106.

Tandelilin, E. (2010). Portofolio dan Investasi Teori dan Aplikasi. Edisi pertama. Kanisius.

Utami, M. R., \& Darmawan, A. (2018). Pengaruh DER, ROA, ROE, EPS dan MVA terhadap harga saham pada indeks saham syariah Indonesia. Journal of Applied Managerial Accounting, 2(2), 206218.

https://doi.org/https://doi.org/10.30 871/jama.v2i2.910

Wicaksono, R. B. (2015). Pengaruh EPS, PER, DER, ROE dan MVA Terhadap Harga Saham. Jurnal Akuntansi, 5(5), 1-13.

Winarto, J. (2005). Penilaian Kinerja Keuangan Perusahaan Menggunakan Metode Market Value Added. Jurnal Manajemen, $4(2), 1-9$. 